\title{
Properties of Blood, Porphyrins, and Exposure to Legacy and Emerging Persistent Organic Pollutants in Surf Scoters (Melanitta perspicillata) Overwintering on the South Coast of British Columbia, Canada
}

\author{
L. K. Wilson • M. L. Harris • S. Trudeau • \\ M. G. Ikonomou $\cdot$ J. E. Elliott
}

Received: 18 March 2009/ Accepted: 30 January 2010/Published online: 5 March 2010

(c) The Author(s) 2010. This article is published with open access at Springerlink.com

\begin{abstract}
The surf scoter (Melanitta perspicillata) is a little-studied species of North American sea duck. Estimates suggest it has experienced a precipitous decline in breeding numbers over the latter half of the past century. To investigate the potential role of contaminant uptake and toxicity in the population decline, this study undertook to measure blood chemistry, porphyrin concentrations, EROD, and organic contaminants in mature surf scoters wintering in the Strait of Georgia, BC, Canada. Hepatic organochlorine pesticide, polychlorinated dibenzo- $p$-dioxin, polychlorinated dibenzofuran, polychlorinated biphenyl (PCB), polybrominated diphenyl ether, and nonylphenol concentrations were relatively low; for example, $\Sigma$ TEQs (toxic equivalents) for PCBs, dioxins, and furans combined ranged
\end{abstract}

\author{
L. K. Wilson \\ Canadian Wildlife Service, Pacific Wildlife Research Centre, \\ Environment Canada, 5421 Robertson Rd., RR1, Delta, \\ BC V4K 3N2, Canada \\ M. L. Harris \\ Lorax Environmental, 136 St. Catherine's Rd., RR3, \\ Bonshaw, PE C0A 1C0, Canada \\ e-mail: mlharris@pei.sympatico.ca \\ S. Trudeau \\ Science \& Technology Branch, Environment Canada, National \\ Wildlife Research Centre, Ottawa, ON V4K 3N2, Canada \\ M. G. Ikonomou \\ Department of Fisheries and Oceans, Contaminants Science \\ Section, Institute of Ocean Sciences, Sidney, BC V8L 4B2, \\ Canada

\section{J. E. Elliott $(\bowtie)$} \\ Science \& Technology Branch, Pacific Wildlife Research \\ Centre, Environment Canada, 5421 Robertson Rd., RR1, Delta, \\ BC V4K 3N2, Canada \\ e-mail: john.elliott@ec.gc.ca
}

from $4.7 \mathrm{ng} / \mathrm{kg}$ wet weight in reference-site (Baynes Sound) birds to $11.4 \mathrm{ng} / \mathrm{kg}$ wet weight in birds from Vancouver Harbour. Nonetheless, elevated EROD activity indicated that birds in Howe Sound were responding to an Ah-receptor-mediated stressor, which was also affecting hematocrit values and possibly vitamin A status. In addition, a low proportion of lymphocytes in individuals across locations in early spring samples was associated with poor body condition. The apparent loss of fitness just prior to the onset of northerly migrations to breeding grounds is of particular concern. Compromised health of mature birds at this point in the season might impact negatively on the productivity and survival of some individuals, particularly those overwintering in Howe Sound.

Surf scoters (Melanitta perspicillata) are 1 of 15 species of sea duck native to North America. As a waterfowl group, sea ducks are one of the most poorly understood, with fundamental gaps in knowledge of such basic life-history traits as habitat preferences, migratory pathways, migratory physiology, and reproductive ecology (SDJVMB 2001). The original (1986) North American Waterfowl Management Plan provided little guidance on sea ducks because their populations were thought to be stable; however, surveys conducted during the 1990s suggested that 10 of the 15 species were experiencing population declines and 3 of these are now listed as endangered or threatened (eastern harlequin ducks Histrionicus histrionicus, spectacled eiders Somateria fischeri, Alaskan stellar's eiders Polysticta stelleri). The surf scoter is one of the species for which the least amount of information is available.

Sea ducks are difficult to study because they typically breed in very low densities across a vast expanse of northern boreal forest and they use a number of migratory pathways to 
travel to extensive marine molting and wintering grounds. The Sea Duck Joint Venture (SDJV) group was established in 1998 to coordinate an international effort aimed at increasing knowledge on sea ducks, their management, and population declines. Priority status was given to studies of basic biology, habitat requirements on breeding and wintering grounds, possible contaminants affecting survival and productivity rates, and means of obtaining accurate harvest estimates (SDJVMB 2001). The research described in this article was part of the SDJV coordinated effort.

Mature surf scoters winter in the sheltered bays and sounds of the Strait of Georgia (British Columbia, Canada) and young birds might remain there year round until they reach maturity (2-3+ years). In recent years, many of these inner coastal wintering grounds have become increasingly developed for urban and recreational use and for salmon and shellfish aquaculture. In addition to habitat infringement, there are contaminant issues, related in particular to urban development, forestry, and shipping. The purpose of the study described here was to investigate the possibility that surf scoters were taking up significant concentrations of contaminants during the winter period spent in the Strait of Georgia and to examine what potential effects their winter stay might have on the adult birds' ability to migrate north and to reproduce successfully.

Upon examining body condition of adult males, we found that their condition deteriorated slightly over the course of one winter season at two locations. Body condition was measured semiquantitatively upon necropsy as fullness of the pectoral muscles and amounts of subcutaneous, omental, and pericardial fat. There was a negative association between body condition and concentrations of tri-butyltins (Elliott et al. 2007). There was also a positive association between renal cadmium and hepatic vitamin A concentrations in the same birds, suggesting an alteration in the vitamin A metabolic pathway by cadmium (Harris et al. 2007). This article describes organic contaminants measured in the same surf scoters and the status of several blood and liver markers routinely used to evaluate stress and organic contaminant exposure.

\section{Materials and Methods}

\section{Field Sites and Tissue Collection Procedures}

Surf scoters were collected from four locations along the southern British Columbia (BC) coast [map of locations is provided in Elliott et al. (2007) and Harris et al. (2007)]. Baynes Sound in the north is a minimum of $35 \mathrm{~km}$ from any industrial activities. Howe Sound, just north of Vancouver, receives treated discharge from two pulp and paper mills. Esquimalt Harbour (Victoria) and Vancouver
Harbour are urban industrialized sites. Initial collections in December 1998 (late fall to early winter) were limited to Baynes and Howe Sounds; subsequent collections in February to March 1999, 2000, and 2001 (late winter to early spring) encompassed the other two sites as well.

Surf scoters were shot from a boat using nontoxic steel loads in Baynes and Howe Sounds. In the two more urban locations, individuals were live-captured using a modification of the mist netting technique described by Kaiser et al. (1995). Mist nets were $2.6 \mathrm{~m}$ high by $18 \mathrm{~m}$ long, with a mesh size of $127 \mathrm{~mm}$ (Avinet Inc., Dryden, NY). Upright poles, $3 \mathrm{~m}$ in length were placed on portable floating rafts. Two nets and three rafts were used and were anchored on land and in the water. Several decoys were placed on either side of the net. Nets were attended by a boat waiting within viewing distance, and birds were retrieved immediately upon entanglement.

Once captured and brought to shore, live birds were anesthetized with isofluorane. Blood was then collected from the jugular vein, and the birds were euthanized with a small volume (1-2 mL) of 99\% isopropyl alcohol injected into the cerebromedullary cistern. Often, birds that were shot had macerated jugular veins; thus, the blood was collected by heart puncture instead. Drops of blood were immediately smeared on glass slides and dried for differential white blood cell counts. Blood in unheparinized tubes was centrifuged in the field for hematocrit measurement. Necropsies were conducted as reported in Elliott et al. (2007). The gall bladder was removed intact and bile transferred to liquid nitrogen for polycyclic aromatic hydrocarbon (PAH) analysis. Portions of liver were transferred after weighing to liquid nitrogen (EROD, porphyrins), buffered formalin (histopathology), or acetone/hexane rinsed jars (organic chemistry analyses). All tissues for contaminants analyses were stored initially at $-20^{\circ} \mathrm{C}$. Samples were shipped to the National Wildlife Research Centre (NWRC, Ottawa, ON) for processing and subsequent archiving in the National Specimen Bank at $-40^{\circ} \mathrm{C}$.

\section{Analysis of Contaminants in Liver and Bile}

Liver samples were analyzed as composites by location and year for concentrations of organochlorines (OCs), polychlorinated biphenyls (PCBs), polychlorinated dibenzo- $p$ dioxins (PCDDs), polychlorinated dibenzofurans (PCDFs), and polybrominated diphenyl ethers (PBDEs). Individual liver and bile samples (nine lost during removal) were analyzed for concentrations of nonylphenols and PAHs, respectively. Analyses were conducted at NWRC unless otherwise stated.

Bile samples were diluted 300-1000 times with 1:1 water:ethanol and analyzed for PAH conjugated (pyrene) metabolites using a synchronous fluorescence scanning 
(SFS) method (Ariese et al. 1993). Fluorescence spectra were recorded with a fixed wavelength difference of $37 \mathrm{~nm}$. This difference was previously reported to be optimal for the detection of pyrene, 1-hydroxypyrene, and benzo(a)pyrene metabolites with a pyrene chromophore (Lin et al. 1994). Spectra were measured on a Perkin-Elmer LS-50B spectrofluorometer and compared to spectra of pyrene-1-glucuronide and 1-hydroxypyrene standards. Samples were also compared to fish samples containing known low, moderate, and high levels of PAHs (J. E. Stein, National Marine Fisheries Service, National Oceanic and Atmospheric Administration). The limit of detection was $30 \mathrm{ng}$ 1-hydroxypyrene equivalents per milliliter of bile.

Hepatic concentrations of OC pesticides and PCB congeners were measured using a multiresidue gas chromatography (GC)/mass selective detector (MSD) technique. Homogenized, dehydrated liver samples were submitted to neutral lipid extraction, gel permeation chromatography, and Florisil column chromatography as cleanup steps prior to chemical quantification (Norstrom et al. 1988; Peakall et al. 1986). Sample extracts were injected twice onto a HP5890 GC equipped with a HP5971 MSD and a 30-m DB-5 fusedsilica column. The first injection was used to measure OCs by comparison with $21 \mathrm{OC}$ standards; the second injection was used to measure PCB congeners against an Aroclor 1242:1254:1260 (1:1:1) standard mixture.

Fifty-nine PCB congener peaks were quantified using the above method, along with 1,2,4,5- and 1,2,3,4-tetrachlorobenzene (TCB), pentachlorobenzene, hexachlorobenzene (HCB), octachlorostyrene (OCS), trans- and cisnonachlor, trans- and cis-chlordane, oxychlordane, heptachlor epoxide (HE), p,p'-dichlorodiphenyldichloroethane (-DDD), $p, p^{\prime}$-dichlorodiphenyldichloroethylene (-DDE), $p, p$ '-dichlorodiphenyltrichloroethane (-DDT), photo-mirex, mirex, $\alpha-, \beta-$, and $\gamma$-hexachlorocyclohexane $(-\mathrm{HCH})$, and dieldrin. A 1989 diluted herring gull egg pool reference material sample was analyzed with each run. Results were expressed on a wet weight basis and were not corrected for percent recoveries. Minimum limits of detection varied from 0.001 to $0.0001 \mu \mathrm{g} / \mathrm{g}$.

Hepatic concentrations of 18 PCDDs, 23 PCDFs, and 6 non-ortho PCBs were measured using a high-resolution GC/MS procedure. The preparatory procedures (neutral extraction, gel permeation chromatography, alumina column cleanup, Florisil column chromatography) have been described by Letcher et al. (1996). Quantification was achieved using a VG AutoSpec double-focusing high-resolution MS linked to a Hewlett-Packard 5890 Series II high-resolution GC with a 30-m DB-5 fused-silica column.

Isotopically labeled $\left({ }^{13} \mathrm{C}_{12}\right)$ internal standards were used for all PCDD, PCDF, and non-ortho PCB congeners measured, and corrections for percent recovery of each individual congener were made. Herring gull egg reference samples were used to check analytical accuracy, as for the OC and PCB analyses above. PCB congeners are described in the text using International Union of Pure and Applied Chemistry (IUPAC) numbers. Minimum detection limits were assessed for each sample and are reported in the results where relevant. Lipid and moisture content were determined using gravimetric methods.

Hepatic concentrations of PBDEs were analyzed in composite samples from Baynes Sound and Vancouver Harbour (1999-2001) at AXYS laboratories (Sidney, BC) using a highresolution GC/MS technique (Hites et al. 2004). Liver homogenates were mixed with nine ${ }^{13} \mathrm{C}_{12}$-labeled BDEs, dehydrated, Soxhlet-extracted, cleaned up on Biobeads SX-3 columns, and fractionated on Florisil silica and alumina chromatography columns. Resulting sample fractions were analyzed on a Micromass Autospec Ultima magnetic sector high-resolution MS linked to a Hewlett-Packard 6890 GC equipped with a Durabond DB5-HT high-temperature column. Data were corrected for recovery of standards. The above method measured 41 PBDE congeners. Results are expressed as wet weight values; detection limits were congener-specific and reported in the text where relevant.

Concentrations of nonylphenol and its ethoxylates in livers of birds collected in Vancouver Harbour in 2001 were measured at the Institute of Ocean Sciences (Sidney, BC). Liver homogenates were mixed with ${ }^{13} \mathrm{C}$-labeled recovery standards (nonylphenol and three ethoxylates) and then extracted with acetone: $\mathrm{CH}_{3} \mathrm{CN}$ :DCM as described by Dods et al. (2005). Extracts were applied to solid-phase extraction columns. Nonylphenol and 19 ethoxylates in concentrated extracts were measured using liquid chromatography/electrospray ionization mass spectrometry. Polyoxyethylene-6myristal ether was used as a QA standard. Values are reported on a wet weight basis and have been corrected for background levels measured in each sample run.

\section{Analysis of Ethoxyresorufin- $O$-deethylase (EROD)} Activity in Liver

Exposure to Ah-receptor-mediated contaminants acting through the cytochrome P450IA pathway was estimated by measuring the activity of 7-ethoxyresorufin- $O$-deethylase (EROD) in liver microsomes according to a modification (Trudeau and Maisonneuve 2001) of the microplate spectrofluorometric method described by Kennedy and Jones (1994).

The reaction mixture in each sample well contained 110 $\mu \mathrm{L}$ of $0.05 \mathrm{M}$ sodium phosphate buffer ( $\mathrm{pH} 8.0$ ), $25 \mu \mathrm{L}$ of microsomes, and $50 \mu \mathrm{L}$ of $2 \mu \mathrm{M}$ 7-ethoxyresorufin in buffer ( $\mathrm{pH} 8.0$ ). This mix was preincubated at $37^{\circ} \mathrm{C}$ for $5 \mathrm{~min}$ before the reaction was initiated with $50 \mu \mathrm{L}$ of $2.4 \mathrm{mM}$ NADPH in phosphate buffer. Microplates were incubated for $10 \mathrm{~min}$ at $37^{\circ} \mathrm{C}$, after which the reaction was 
stopped with the addition of $100 \mu \mathrm{L}$ cold acetonitrile containing fluorescamine $(600 \mu \mathrm{g} / \mathrm{mL})$. Plates were scanned with a fluorescence multiwell plate reader (Cytofluor Model 2350) for resorufin at 530-nm excitation and 590$\mathrm{nm}$ emission wavelengths and for protein at $400-\mathrm{nm}$ excitation and 460-nm emission wavelengths. Five concentrations of resorufin standard and bovine serum albumin blanks and one avian reference sample were analyzed on each microplate. Concentrations of standards were verified spectrophotometrically (HP photodiode array, HP8452). Samples were run in triplicate.

\section{Analysis of Porphyrins in Liver}

Hepatic concentrations of porphyrins were measured using the high-performance liquid chromatography (HPLC) technique described by Kennedy and James (1993). Approximately $100-\mathrm{mg}$ minced samples of liver were spiked with a mesoporphyrin standard and extracted with $6 \mathrm{~mL}$ of $1 \mathrm{~N} \mathrm{HCl}$ :acetonitrile (1:1) in two homogenization and centrifugation $(2 \times 1000 \times g$ for $15 \mathrm{~min}$ each time $)$ steps. Porphyrins in the combined supernatant were concentrated on Sep-Pak $+\mathrm{C} 18$ cartridges. Extracts were analyzed by reverse-phase HPLC (Pecosphere octadecylsilyl column, Varian 9010-2332, 9100-2659) equipped with a Perkin-Elmer LS-4 fluorescence detector (400-nm excitation and 624-nm emission wavelengths). The method measures six porphyrins (viz. uro-, hepta-, hexa-, penta-, copro- and proto-porphyrin); calibration curves were prepared for each porphyrin using five concentrations and stock solutions were verified spectrophotometrically. Samples were reextracted if recovery of the mesoporphyrin standard was $<85 \%$.

In some cases for which there was strong interference after the uroporphyrin peak, extracts were reanalyzed using a modification of the isomer separation method described by Lim (1991). This method uses the same analytical column, detector, and detection wavelengths as described earlier but a different mobile phase (1 $\mathrm{M}$ ammonium acetate buffer $\mathrm{pH} 5.2$, vs. the phosphate buffer) and gradient.

\section{Assessment of Blood Parameters and Histopathology}

Blood smears were made prior to necropsy of birds and allowed to air-dry. Smears were fixed with methyl alcohol and stained with Hemacolor stain; the first 100 white blood cells were identified as heterophils, eosinophils, monocytes, or lymphocytes. The heterophil/lymphocyte ratio was derived, as it is a stress estimator commonly applied for poultry (Maxwell 1993).

Kidney, gonad, and adrenal gland tissues were preserved in neutral buffered formalin and later embedded in paraffin, sectioned, and stained with hematoxylin \& eosin for histopathological assessments (Humason 1972). Pathology was examined in a semiquantitative manner, using ranking on scales of 1-3 or 4, depending on the end point. Kidneys were assessed for abnormalities including granulomas, evidence of autolysis and interstitial inflammation. Adrenal glands were examined for presence of parasites, the relative proportions of cortical and medullary tissue, and the presence of necrotic or inflammatory foci. The seminiferous tubules of testes were assessed for evidence of spermatogenesis and apoptotic cells. Ovaries were assessed for evidence of follicular development, including atretic follicles. The medullary stroma of ovaries and interstitial tissue of testes were examined for inflammatory foci.

\section{Statistical Evaluation}

All statistical assessments were conducted using SYSTAT 5.0 (Wilkinson 1990). Values for EROD and porphyrins were log-transformed, whereas white blood cell proportions and hematocrit values were arcsine-transformed prior to analyses, to meet assumptions of normality and heterogeneity of variances. Histopathology scores were assessed using nonparametric (Kruskal-Wallis) techniques.

A subset of adult males collected 3-15 December 1998 and 1-2 March 1999 from Baynes and Howe Sounds were used to establish whether birds newly arrived from molting grounds showed differences in EROD activity, porphyrin concentrations, blood parameters, or histopathology compared to birds that had overwintered in the marine sounds of the Strait of Georgia. The effects of the independent variables, collection date, and location on EROD and blood parameters were tested using multivariate analyses of variance (MANOVAs). Their effects on porphyrins were tested using multivariate analyses of covariance (MANCOVAs), where the covariate for coproporphyrin and Shighly carboxylated porphyrins (uroporphyrin + hepta- + hexa-carboxylic acid porphyrins) was protoporphyrin and the covariates for protoporphyrin were uroporphyrin and coproporphyrin. Where a significant interaction existed between the two independent variables, the effect of collection date was assessed separately for each of the locations. Where a significant interaction existed between an independent variable and a covariate, graphic assessments were made as a nonstatistical alternative.

Interlocation variability in biological parameters of male surf scoters throughout the Strait of Georgia was assessed using data from all four overwintering sites wherever possible. Where stepwise testing found no significant differences within a location, the collection date was dropped as an independent variable and univariate ANOVAs were conducted as earlier with the single independent variable location. If the collection date had a significant effect, then 
a smaller subset of males all collected in February-March 1999 was assessed.

Contaminant associations with biological parameters in surf scoters were evaluated using Bonferroni-adjusted Pearson correlations. Because organics analyses were performed on composite samples made up of all individuals collected at the same location on the same date, matching arithmetic mean values for biological measurements were used in correlation analyses. TCDD-toxic equivalents (TEQs) were measured by summing the factors (TEFs) for PCDDs, PCDFs, and PCBs recommended for birds by Van den Berg et al. (1998).

\section{Results}

Organic Contaminant Profiles

Seven composite liver samples were analyzed for PCDDs, PCDFs, PCBs, and OCs; most samples had detectable concentrations of only a few of the major OC compounds and a number of PCDD, PCDF, and PCB congeners (Table 1). These could not be statistically compared because they were pooled for chemical analysis. Dominant congeners were 1,2,3,7,8-PnCDD, 2,3,7,8-TCDF, PCB-77, and PCB-126. TEQs were slightly, but consistently, elevated above reference (Baynes Sound) levels at the two harbor sites, Vancouver and Esquimalt (Table 1). Howe Sound birds showed low TEQs in the late fall (1998) but levels comparable to the harbor site birds by the early spring (1999). Baynes and Howe Sound birds both also acquired higher concentrations of $\Sigma$ PCBs and $p, p^{\prime}$-DDE while overwintering. Early spring values were comparable to those of birds collected around the same time at Vancouver Harbour (Table 1). Traces of chlordanes and HCB were found in birds from all locations, whereas all other OC pesticides were below detection limits.

Polybrominated diphenyl ethers were only measured in Vancouver Harbour and Baynes Sound samples and total concentrations in birds from the urban harbor were slightly lower than total PCBs (Table 1). Reference-site birds showed much lower PBDE concentrations compared to their PCB tissue burden and compared to 5 PBDEs in Vancouver Harbour birds. Although $22 \mathrm{BDE}$ congeners were detected in liver samples, the 7 listed in Table 1 constituted $98 \%$ of the total concentration of hepatic PBDEs. The pattern of congener dominance in birds collected from the urban Vancouver Harbour was BDE-99 > BDE-100 > BDE$47 \sim$ BDE-153 BDE-209 BDE-154 > BDE-183. The pattern in birds collected from the reference site, Baynes Sound, was BDE-153 > BDE-99 BDE-209 BDE$100 \sim$ BDE-154 > BDE-47 > BDE-183.

Bile concentrations of PAH (pyrene) metabolites were typically nondetectable $(n=58)$ with the following exceptions: two adult males from Vancouver Harbour (299 ng/mL pyrene glucuronide, trace benzo( $a$ )pyrene conjugated metabolite); two juvenile males from Esquimalt Harbour ( 75 and $154 \mathrm{ng} / \mathrm{mL}$ pyrene glucuronide); and one juvenile female from Howe Sound (trace pyrene glucuronide).

Nonylphenols were measured in individual liver samples from birds collected in Vancouver Harbour in the early spring of 2001 alone. Nonylphenol and 15 ethoxylates were detected in 11 of 16 samples. Total concentrations ranged widely from 1 to $981 \mathrm{ng} / \mathrm{g}$ wet weight (ww), with a geometric mean value of $72.4 \mathrm{ng} / \mathrm{g} \mathrm{ww}$ (Table 2).

\section{Biological Changes Associated with Overwintering}

There were few significant seasonal changes in biological end points in adult male birds from Baynes and Howe Sounds (fall collections were not made at Vancouver or Esquimalt Harbours). There were no significant seasonal changes in hepatic EROD activity, hematocrit values, or histopathology of kidneys or testes.

The proportion of lymphocytes in males decreased significantly at Baynes Sound ( $p=0.007, n=15)$ between late fall and early spring. Although the decrease in lymphocyte proportion was also evident at Howe Sound, it was not significant. Over the same period, the proportion of eosinophils increased at both locations $(p=0.00001$, $n=27$ ). The prevalence of lymphocytes in male peripheral blood samples was significantly positively correlated with a semiquantitative measure of body condition [Pearson $r=0.484, p=0.01, n=27$; body condition reported in Elliott et al. (2007) as a rank description of fullness of pectoral muscles and amounts of subcutaneous, omental, and pericardial fat].

The assessment of seasonal changes in hepatic porphyrin concentrations was impeded by the existence of significant interactions between collection date and the relevant covariate (protoporphyrin, $p=0.02$, or uroporphyrin, $p=0.0003$ ). This suggested that the metabolism of porphyrin changed between fall and spring. A graphic examination of the proportionality of single porphyrins to total porphyrins ( $\Sigma$ [uroporphyrin + hepta- + hexa- + pentacarboxylic porphyrins + coproporphyrin + protoporphyrin]) supported and expanded upon this statistical finding, as it indicated that a number of spring samples showed greater relative concentrations of coproporphyrin (Fig. 1). This made the examination of seasonal changes in absolute concentrations of single porphyrins irrelevant.

Variability Associated with Location

Hepatic EROD activity and blood hematocrit values showed no significant seasonal or yearly variability within 
Table 1 Concentrations of organic contaminants in composite (pooled) liver samples from surf scoters collected in the Strait of Georgia, BC, Canada, 1998 to 2001

\begin{tabular}{|c|c|c|c|c|c|c|c|}
\hline \multirow[b]{2}{*}{$\begin{array}{l}\text { Collection date } \\
n \\
\text { Gender, age }\end{array}$} & \multicolumn{2}{|l|}{ Baynes Sound } & \multirow{2}{*}{$\begin{array}{l}\text { Esquimalt Harbour } \\
\text { Mar. } 00 \\
4 \\
1 \mathrm{~J}_{\text {}} \text { 3 } 3 \mathrm{~J}_{\widehat{O}}\end{array}$} & \multicolumn{2}{|c|}{ Howe Sound } & \multicolumn{2}{|l|}{ Vancouver Harbour } \\
\hline & $\begin{array}{l}\text { Dec. } 98 \\
11 \\
2 \mathrm{~A} \text { 우 } 6 \mathrm{~A}_{0}^{\widehat{3}} 3 \mathrm{~J}_{\widehat{3}}\end{array}$ & $\begin{array}{l}\text { Mar. } 99 \\
11 \\
1 \mathrm{~A}+1 \mathrm{~J}+9 \mathrm{~A}^{\widehat{A}}\end{array}$ & & $\begin{array}{l}\text { Dec. } 98 \\
10 \\
3 \mathrm{~A}^{\circ} 7 \mathrm{~A} \widehat{\jmath}\end{array}$ & $\begin{array}{l}\text { Mar. } 99 \\
10 \\
1 \mathrm{~A}+4 \mathrm{~J} \text { 和 }\end{array}$ & 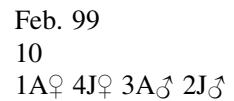 & $\begin{array}{l}\text { Feb. } 01 \\
16 \\
6 \mathrm{~A} \text { 우 } 10 \mathrm{~A}^{\Im}\end{array}$ \\
\hline \multicolumn{8}{|c|}{ PCDDs, PCDFs, and non-ortho PCBs (ng/kg) } \\
\hline $2,3,7,8-\mathrm{TCDD}$ & $<0.25$ & 0.17 & 0.13 & $<0.53$ & 0.41 & 0.29 & 0.41 \\
\hline $1,2,3,7,8-\mathrm{PnCDD}$ & 0.50 & 0.62 & 0.52 & $<0.23$ & 0.90 & 0.84 & 0.77 \\
\hline $1,2,3,4,7,8-\mathrm{HxCDD}$ & $<0.10$ & $<0.06$ & 0.16 & $<0.25$ & 0.13 & 0.19 & $<0.04$ \\
\hline $1,2,3,6,7,8-\mathrm{HxCDD}$ & 0.66 & 0.90 & 0.71 & $<0.25$ & 1.08 & 0.79 & 1.25 \\
\hline $1,2,3,7,8,9-\mathrm{HxCDD}$ & 0.10 & $<0.03$ & $<0.15$ & $<0.25$ & 0.18 & 0.16 & 0.18 \\
\hline $1,2,3,4,6,7,8-\mathrm{HpCDD}$ & $<0.20$ & 0.33 & 0.37 & 0.52 & 0.61 & 0.70 & 0.73 \\
\hline OCDD & 0.31 & 0.30 & 0.60 & 0.38 & 0.63 & 0.63 & 1.34 \\
\hline $2,4,6,8-\mathrm{TCDF}$ & $<0.10$ & $<0.06$ & 0.33 & $<0.13$ & $<0.03$ & $<0.02$ & 0.43 \\
\hline $2,3,7,8-\mathrm{TCDF}$ & 1.94 & 1.62 & 2.00 & 0.91 & 3.06 & 2.51 & 3.25 \\
\hline $2,3,6,7-\mathrm{TCDF}$ & $<0.10$ & $<0.06$ & 0.76 & 0.49 & 1.19 & 0.97 & 0.92 \\
\hline $1,2,4,6,8-\mathrm{PnCDF}$ & $<0.09$ & 0.32 & 0.41 & 0.16 & 0.29 & 0.34 & 0.27 \\
\hline $1,2,3,6,8-\mathrm{PnCDF}$ & $<0.09$ & $<0.08$ & $<0.20$ & $<0.15$ & $<0.10$ & 0.05 & $<0.05$ \\
\hline $1,2,4,7,8-\mathrm{PnCDF}$ & $<0.09$ & 0.22 & 0.57 & 0.28 & 0.31 & 0.38 & 0.47 \\
\hline $1,2,3,7,8-\mathrm{PnCDF}$ & 0.09 & 0.13 & $<0.20$ & $<0.15$ & 0.22 & 0.24 & 0.26 \\
\hline 2,3,4,7,8-PnCDF & 0.35 & $<0.08$ & 0.57 & 0.22 & 0.70 & 0.71 & 0.71 \\
\hline $2,3,4,6,7-\mathrm{PnCDF}$ & $<0.09$ & $<0.08$ & $<0.20$ & $<0.15$ & 0.18 & 0.21 & 0.17 \\
\hline $1,2,4,6,7,8-\mathrm{HxCDF}$ & $<0.06$ & $<0.08$ & $<0.10$ & $<0.20$ & $<0.10$ & 0.08 & $<0.08$ \\
\hline $1,2,4,6,8,9-\mathrm{HxCDF}$ & $<0.60$ & 0.17 & 0.16 & $<0.20$ & 0.34 & 0.51 & 0.37 \\
\hline $1,2,3,4,7,8-\mathrm{HxCDF}$ & $<0.06$ & 0.17 & 0.18 & $<0.20$ & 0.13 & 0.13 & 0.12 \\
\hline $1,2,3,6,7,8-\mathrm{HxCDF}$ & $<0.06$ & 0.08 & 0.10 & $<0.20$ & $<0.10$ & 0.05 & 0.10 \\
\hline 1,2,3,7,8,9-HxCDF & $<0.06$ & $<0.08$ & 0.11 & $<0.20$ & $<0.10$ & 0.09 & $<0.08$ \\
\hline $1,2,3,4,6,7,8-\mathrm{HpCDF}$ & 0.04 & 0.13 & $<0.19$ & $<0.16$ & $<0.10$ & 0.10 & 0.21 \\
\hline $1,2,3,4,7,8,9-\mathrm{HpCDF}$ & $<0.04$ & 0.07 & $<0.19$ & $<0.16$ & $<0.10$ & $<0.10$ & $<0.10$ \\
\hline OCDF & $<0.20$ & $<0.30$ & 0.40 & $<0.04$ & 0.20 & $<0.05$ & 0.36 \\
\hline PCB-37 & 2.84 & 3.13 & 11.71 & 5.50 & 16.11 & 14.37 & 11.74 \\
\hline PCB-81 & 0.87 & 1.22 & 2.98 & 0.95 & 0.36 & 2.80 & 4.94 \\
\hline PCB-77 & 21.57 & 27.25 & 59.19 & 14.78 & 60.90 & 62.29 & 81.52 \\
\hline PCB-126 & 4.74 & 6.64 & 8.80 & 4.20 & 13.28 & 11.98 & 15.79 \\
\hline PCB-169 & 1.25 & 1.78 & 1.52 & 0.58 & $<0.16$ & 1.30 & 3.30 \\
\hline PCB-189 & $<0.50$ & 0.32 & $<0.33$ & $<0.13$ & $<0.16$ & $<0.38$ & $<0.51$ \\
\hline$\Sigma$ TEQs & 4.73 & 4.66 & 7.43 & 2.68 & 9.56 & 9.03 & 11.38 \\
\hline \multicolumn{8}{|l|}{ PBDEs $(\mu \mathrm{g} / \mathrm{g})$} \\
\hline BDE-47 & - & 0.00012 & - & - & - & 0.00241 & 0.00082 \\
\hline BDE-99 & - & 0.00045 & - & - & - & 0.00645 & 0.00212 \\
\hline BDE-100 & - & 0.00037 & - & - & - & 0.00498 & 0.00168 \\
\hline BDE-153 & - & 0.00057 & - & - & - & 0.00145 & 0.00094 \\
\hline BDE-154 & - & 0.00036 & - & - & - & 0.00178 & 0.00066 \\
\hline BDE-183 & - & 0.00002 & - & - & - & 0.00015 & 0.00007 \\
\hline BDE-209 & - & 0.00041 & - & - & - & 0.00157 & 0.00098 \\
\hline$\Sigma$ PBDEs & - & 0.00234 & - & - & - & 0.01925 & 0.00743 \\
\hline$\Sigma$ PCBs $(\mu \mathrm{g} / \mathrm{g})$ & 0.003 & 0.010 & 0.009 & 0.002 & 0.033 & 0.022 & 0.014 \\
\hline$p, p^{\prime}-\mathrm{DDE}(\mu \mathrm{g} / \mathrm{g})$ & 0.007 & 0.013 & 0.005 & 0.002 & 0.016 & 0.018 & 0.015 \\
\hline$\Sigma$ Chlordane $(\mu \mathrm{g} / \mathrm{g})$ & $<0.0009$ & 0.002 & $<0.0009$ & $<0.0009$ & 0.001 & $<0.0001$ & 0.001 \\
\hline $\mathrm{HCB}(\mu \mathrm{g} / \mathrm{g})$ & $<0.0009$ & 0.002 & 0.002 & $<0.0009$ & 0.001 & $<0.0009$ & 0.001 \\
\hline
\end{tabular}


Table 2 Concentrations of total nonylphenol and ethoxylates (ng/g ww, geometric means [G.M.], upper and lower 95\% confidence limits [C.L.], minimums and maximums) in individual liver samples from surf scoters collected in Vancouver Harbour, spring 2001

\begin{tabular}{|c|c|c|c|c|c|c|}
\hline \multirow{3}{*}{$N$, Age } & \multicolumn{3}{|c|}{ Females } & \multicolumn{3}{|l|}{ Males } \\
\hline & \multicolumn{3}{|l|}{$6 \mathrm{~A}$} & \multicolumn{3}{|l|}{$10 \mathrm{~A}$} \\
\hline & G.M. & C.L. & Min, Max & G.M. & C.L. & Min, Max \\
\hline NP2 Ethoxylates & 3.9 & $0.2,19.5$ & $<4.2-76.3$ & & & $<4.5$ \\
\hline NP3 Ethoxylates & 5.5 & $0.3,32.2$ & $<2.8-71.5$ & & & $<7.4$ \\
\hline NP4 Ethoxylates & 2.0 & $0,11.4$ & $<1.5-45.8$ & 4.7 & $0.8,16.9$ & $<4.2-84.7$ \\
\hline NP5 Ethoxylates & 1.8 & $0.2,5.5$ & $<2.0-13.6$ & 4.3 & $0.7,16.1$ & $<3.8-91.6$ \\
\hline NP6 Ethoxylates & 4.7 & $0.5,20.3$ & $<1.9-92.1$ & 7.2 & $1.0,32.9$ & $<6.7-125$ \\
\hline NP7 Ethoxylates & 5.1 & $0.6,22.3$ & $<1.9-29.5$ & 5.8 & $1.0,22.4$ & $<3.9-145$ \\
\hline NP8 Ethoxylates & 5.4 & $0.5,26.2$ & $<1.8-31.2$ & 6.7 & $1.3,25.1$ & $<4.6-152$ \\
\hline NP9 Ethoxylates & 3.7 & $0.3,15.7$ & $<1.6-25.2$ & 5.8 & $1.0,21.4$ & $<4.0-123$ \\
\hline NP10 Ethoxylates & 3.6 & $0.3,15.6$ & $<2.0-38.1$ & 4.6 & $0.9,15.9$ & $<3.4-105$ \\
\hline NP11 Ethoxylates & 2.9 & $0.1,12.4$ & $<1.7-29.2$ & 3.7 & $0.7,12.0$ & $<3.5-61.4$ \\
\hline NP12 Ethoxylates & 2.5 & $0.1,10.3$ & $<1.6-21.6$ & 2.8 & $0.6,8.0$ & $<3.2-37.5$ \\
\hline NP13 Ethoxylates & 1.7 & $0.2,4.9$ & $<1.7-9.7$ & 2.3 & $0.7,5.5$ & $<3.0-27.7$ \\
\hline NP14 Ethoxylates & 1.9 & $0.4,5.1$ & $<1.7-7.6$ & 1.8 & $0.5,4.1$ & $<3.0-14.8$ \\
\hline NP15 Ethoxylates & 1.5 & $0.6,2.9$ & $<1.8-3.7$ & 1.2 & $0.6,2.2$ & $<3.6-8.2$ \\
\hline NP16 Ethoxylates & 1.0 & $0.3,1.9$ & $<1.4-3.2$ & 0.9 & $0.4,1.6$ & $<3.3-5.1$ \\
\hline Nonylphenol & 12.4 & $0.1,134$ & $<0.7-134$ & 5.5 & $0.4,29.2$ & $<0.7-191$ \\
\hline ¿Nonylphenols & 93.2 & $21.3,398$ & & 92.7 & $28.1,301$ & \\
\hline
\end{tabular}

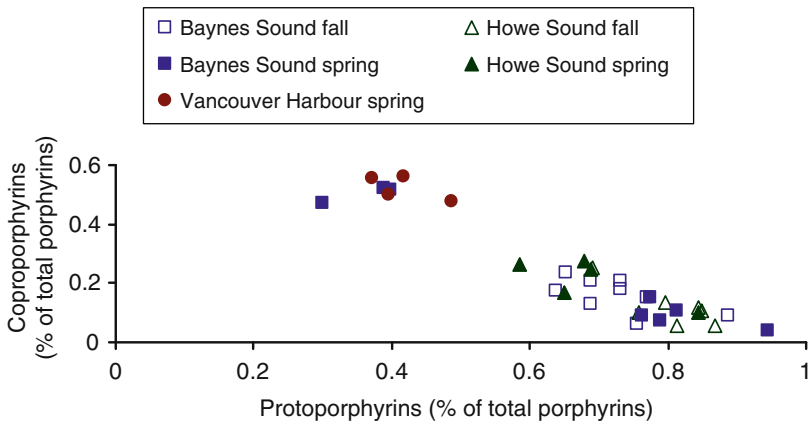

Fig. 1 The variable composition of hepatic concentrations of total porphyrins, expressed as proportion of protophorphyrin relative to proportion of coproporphyrin, in adult male surf scoters collected during the late fall 1998 (December) and early spring 1999 (2 March) in the Strait of Georgia, BC

each location sample population; however, there were significant differences in both variables among locations (Fig. 2, Table 3). EROD was significantly elevated $(p=0.001, n=40)$ and hematocrit significantly depressed ( $p=0.002, n=40$ ) in adult male birds collected from Howe Sound, compared to the reference birds at Baynes Sound or the neighboring population in Vancouver Harbour. Moreover, there was a significant negative correlation between EROD and hematocrit (Pearson $r=-0.479$, $p=0.005)$, most apparent in the Howe Sound individuals (Fig. 2). Although low sample sizes precluded similar assessments with female birds, it is worth noting that juvenile females from Howe Sound exhibited the most elevated EROD activity; three individuals showed values above $250 \mathrm{pmol} / \mathrm{mg}$ protein/min (Table 3).

There was considerable seasonal and yearly variability in differential white blood cell counts, which precluded the pooling of data collected at different times. However, an assessment of adult males collected from three locations at one time, in the early spring of 1999, indicated that the proportional representation of lymphocytes was significantly lower ( $p=0.01, n=17)$ and heterophils significantly higher ( $p=0.05, n=17)$ in birds from the reference site, Baynes Sound, compared to those from Howe Sound (Fig. 3). A nonstatistical comparison of individuals collected from Vancouver Harbour 2 years later indicated that there was a far greater elevation of the heterophil:lymphocyte ratio in harbor-site birds at another point in time, apparent in both males and females (Fig. 3). In an assessment of all adult male surf scoters collected during the study, there were significant positive associations found between the prevalence of lymphocytes and both the total body mass (Pearson $r=0.636$, $p=0.0005, n=32$ ) and the prevalence of parasites in the adrenal glands (Pearson $r=0.608, p=0.001$ ). This was largely due to coinciding relatively low lymphocyte proportions, low body mass, and low parasite incidence (0 to 1 on a rank-scale of 0 to 3 ) in males collected from Vancouver Harbour in February 2001. 

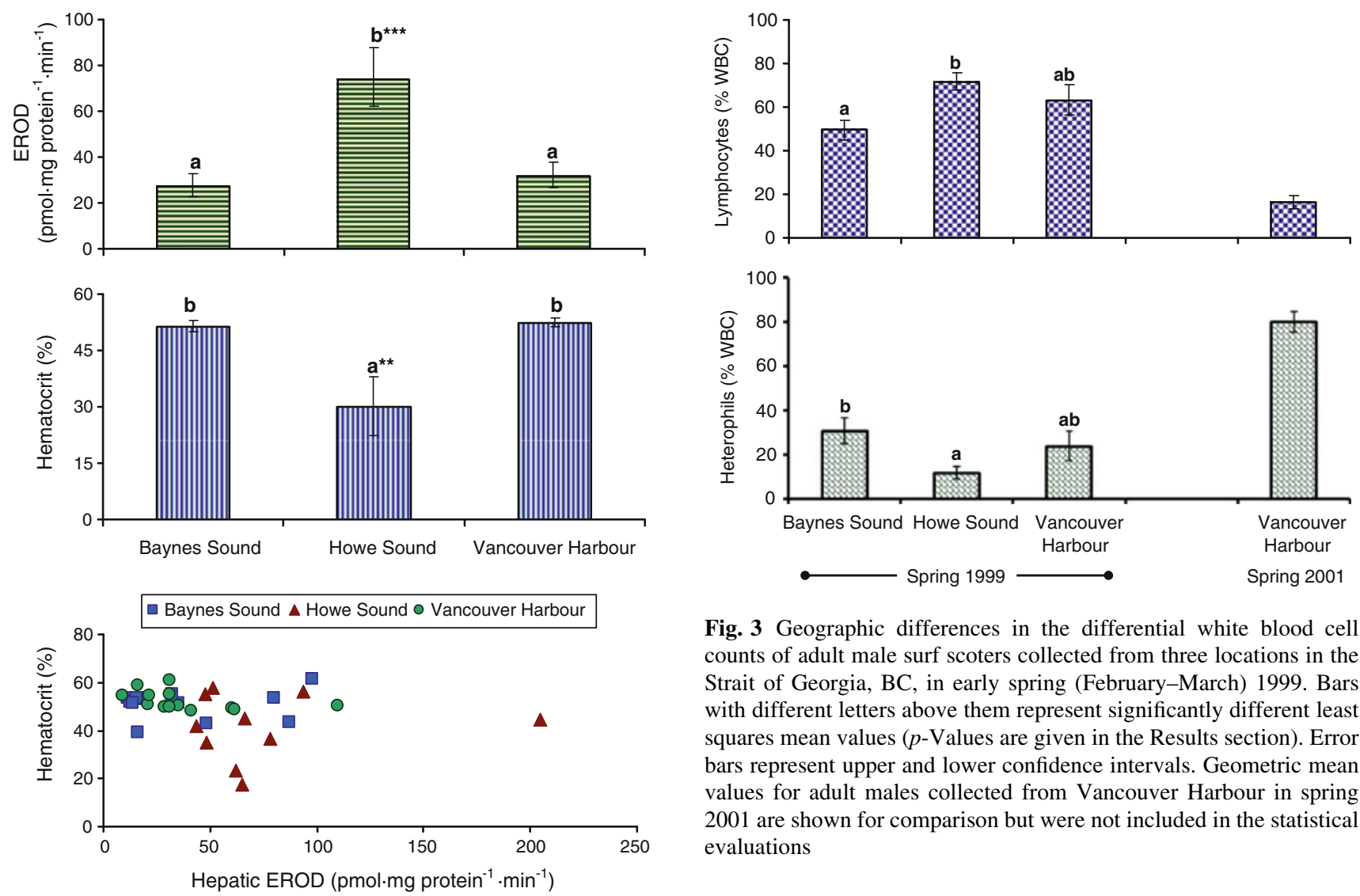

Fig. 3 Geographic differences in the differential white blood cell counts of adult male surf scoters collected from three locations in the Strait of Georgia, BC, in early spring (February-March) 1999. Bars with different letters above them represent significantly different least squares mean values ( $p$-Values are given in the Results section). Error bars represent upper and lower confidence intervals. Geometric mean values for adult males collected from Vancouver Harbour in spring 2001 are shown for comparison but were not included in the statistical evaluations

Fig. 2 The geographic differences in hepatic EROD activity and hematocrit values of adult male surf scoters collected from three locations in the Strait of Georgia, BC, 1998-2001. The significant association between EROD and hematocrit values is expressed in the bottom graph (see results text for $r$ and $p$-values). Bars with different letters above them represent significantly different least squares mean values. Error bars represent upper and lower confidence intervals. $* * p<0.01 ; * * * p<0.001$

The hepatic porphyrins also showed significant geographic differences in adult males collected in early spring 1999 (Table 4). Concentrations of coproporphyrin were

significantly elevated in birds from Vancouver Harbour compared to birds from Howe Sound $(p=0.02)$ or the reference site, Baynes Sound ( $p=0.05$ ). Concentrations of protoporphyrin were significantly depressed in birds from Howe Sound compared to birds from Vancouver Harbour $(p=0.04)$ and Baynes Sound $(p=0.05)$. The highly carboxylated porphyrins were not significantly different among locations $(p=0.06, n=16)$. There were no interaction effects between the location variable and any covariate; hence, it was also suitable to evaluate total porphyrins. In the early spring of 1999, premigratory

Table 3 Hepatic EROD activity and blood hematocrit (geometric means, 95\% confidence limits, minimum-maximum) in surf scoters collected in the Strait of Georgia, BC, Canada, 1998-2001

\begin{tabular}{|c|c|c|c|c|c|c|c|c|}
\hline \multirow[b]{2}{*}{ Age, $n$} & \multicolumn{4}{|l|}{ Females } & \multicolumn{4}{|l|}{ Males } \\
\hline & $\begin{array}{l}\text { Baynes } \\
\text { Sound } \\
3 \mathrm{~A}, 1 \mathrm{~J}\end{array}$ & $\begin{array}{l}\text { Esquimalt } \\
\text { Harbour } \\
1 \mathrm{~J}\end{array}$ & $\begin{array}{l}\text { Howe } \\
\text { Sound } \\
4 \mathrm{~A}, 4 \mathrm{~J}\end{array}$ & $\begin{array}{l}\text { Vancouver } \\
\text { Harbour } \\
7 \mathrm{~A}, 4 \mathrm{~J}\end{array}$ & $\begin{array}{l}\text { Baynes } \\
\text { Sound } \\
15 \mathrm{~A}, 3 \mathrm{~J}\end{array}$ & $\begin{array}{l}\text { Esquimalt } \\
\text { Harbour } \\
3 \mathrm{~J}\end{array}$ & $\begin{array}{l}\text { Howe } \\
\text { Sound } \\
12 \mathrm{~A}\end{array}$ & $\begin{array}{l}\text { Vancouver } \\
\text { Harbour } \\
13 \mathrm{~A}, 2 \mathrm{~J}\end{array}$ \\
\hline \multirow{3}{*}{$\begin{array}{l}\text { EROD }(\mathrm{pmol} / \mathrm{mg} \\
\text { protein } / \mathrm{min})\end{array}$} & 42.6 & 16.1 & 101 & 33.5 & 28.3 & 26.0 & 73.9 & 34.0 \\
\hline & $15.5,117$ & & $45.7,223$ & $1.3,60.3$ & $20.2,39.6$ & $1.4,491$ & $50.8,107$ & $23.5,49.3$ \\
\hline & $25.2-107$ & & $32.4-345$ & $5.8-110$ & $11.5-97.6$ & $8.7-91.2$ & $43.7-270$ & $8.9-110$ \\
\hline \multirow[t]{3}{*}{ Hematocrit (\%) } & 53 & 57 & 45 & 55 & 53 & 58 & 39 & 52 \\
\hline & 42,66 & & 34,59 & 52,58 & 49,56 & 52,64 & 30,50 & 50,54 \\
\hline & $43-60$ & & $23-60$ & $46-64$ & $39-63$ & $55-60$ & $18-58$ & $48-61$ \\
\hline
\end{tabular}


Table 4 Hepatic concentrations of porphyrins (pmol/g) in surf scoters collected in the Strait of Georgia, BC, Canada, 1998-2001

\begin{tabular}{|c|c|c|c|c|}
\hline Location & $n$ & $\Sigma$ Highly carboxylated porphyrins & Coproporphyrin & Protoporphyrin \\
\hline Adult males (1999) & & $1 \mathrm{sm}(\mathrm{m}-\mathrm{m})$ & $1 \mathrm{sm}(\mathrm{m}-\mathrm{m})$ & alsm (m-m) \\
\hline Baynes Sound & 8 & $23.4(12-59)$ & $43.8(13-221)^{\mathbf{a}} *$ & $170(77-791)^{\mathbf{b}} *$ \\
\hline Howe Sound & 5 & $12.1(7-21)$ & $28.3(16-44)^{\mathbf{a} *}$ & $86(73-136)^{\mathbf{a}}$ \\
\hline Vancouver Harbour & 3 & $30.8(19-57)$ & $232(128-421)^{\mathbf{b}}$ & $204(102-281)^{\mathbf{b}} *$ \\
\hline All males (1998-2001) & & $\operatorname{gm}(\mathrm{CL}, \mathrm{m}-\mathrm{m})$ & gm $(\mathrm{CL}, \mathrm{m}-\mathrm{m})$ & $\operatorname{gm}(\mathrm{CL}, \mathrm{m}-\mathrm{m})$ \\
\hline Baynes Sound & 17 & $21.3(15.7,28.9,7-59)$ & $35.8(23.5,54.7,13-221)$ & $153(118,197,77-791)$ \\
\hline Esquimalt Harbour & 3 & $65.9(19.3,225,38-98)$ & $61.7(15.1,252,41-118)$ & $145(88.1,237,115-163)$ \\
\hline Howe Sound & 12 & $13.1(9.1,18.8,7-30)$ & $23.1(17.7,30.0,14-44)$ & $127(97.9,166,73-339)$ \\
\hline Vancouver Harbour & 14 & $29.6(19.4,45.4,9-174)$ & $64.0(35.4,116,23-421)$ & $138(102,185,67-301)$ \\
\hline All females (1998-2001) & & $\mathrm{gm}(\mathrm{CL}, \mathrm{m}-\mathrm{m})$ & $\mathrm{gm}(\mathrm{CL}, \mathrm{m}-\mathrm{m})$ & $\mathrm{gm}(\mathrm{CL}, \mathrm{m}-\mathrm{m})$ \\
\hline Baynes Sound & 4 & $60.3(26.6,136,29-96)$ & $33.7(11.3,101,20-74)$ & $107(47.1,243,53-161)$ \\
\hline Esquimalt Harbour & 1 & 62 & 52 & 174 \\
\hline Howe Sound & 8 & $18.7(15.0,23.2,12-28)$ & $25.6(18.3,35.8,19-51)$ & $207(148,289,94-322)$ \\
\hline Vancouver Harbour & 11 & $20.8(14.9,29.0,6-36)$ & $83.0(41.5,166,25-975)$ & $183(143,233,99-363)$ \\
\hline
\end{tabular}

Note: Letters in bold superscript (adult males 1999 section) indicate significantly different values $(* p<0.05)$. lsm $=$ least squares mean; alsm = adjusted least squares mean (significant covariate uroporphyrin); gm = geometric mean; CL = upper and lower 95\% confidence limits; $\mathrm{m}-\mathrm{m}=$ minimum to maximum

mature males from Vancouver Harbour showed significantly greater absolute concentrations of total hepatic porphyrins $($ mean $=512 \mathrm{pmol} / \mathrm{g})$ than males from Howe Sound $($ mean $=144 \mathrm{pmol} / \mathrm{g}, \quad p=0.005)$. Males from Baynes Sound showed intermediate levels (mean $=267$ $\mathrm{pmol} / \mathrm{g}$ ) that were not different from males at either of the two other locations.

Relationships Between Organic Contaminants and Biological End Points

Due to the pooling of livers for organic chemistry, correlations could only be assessed by comparing single composite values for contaminants with arithmetic mean values for biological end points (grouped by location and collection date). Few relationships were found with this method. Hepatic concentrations of PCB 169 were significantly correlated with differential blood counts of heterophils (Pearson $r=0.956, p=0.005$ ) and lymphocytes (Pearson $r=-0.946, p=0.008)$. No other associations between contaminants or TEQs and average values for EROD and porphyrins were found.

\section{Discussion}

\section{Organic Contaminant Profiles}

Concentrations of OC pesticides and PCBs were low in surf scoter livers, which is consistent with data for other benthivorous marine birds (Elliott and Martin 1998; Fox et al.
2005; Henny et al.1995). Populations of piscivorous birds in the Strait of Georgia have historically been more affected by forestry-sourced PCDDs and PCDFs; however, the effluent and process improvements made at coastal pulp mills in the early 1990s had a positive impact on tissue burdens of dioxins and furans in resident fish-eating birds (Elliott et al. 2001; Harris et al. 2003). Concentrations of PBDEs were comparable to values measured in livers of European populations of cormorants (Phalacrocorax carbo; Law et al. 2002) and glaucous gulls (Larus hyperboreus; Herzke et al. 2003). The congener pattern was different from that reported for other aquatic species (Law et al. 2003), in that BDE-47 was not the dominant congener and several of the more highly brominated congeners (BDE-209 in particular) were present at relatively high concentrations. Most of the common PBDEs found in surf scoter livers (PBDE-99, -100, -153, -47, and -154) are prevalent in the commercial penta-BDE formulation, consistent with ongoing production and use in North America at the time of sampling (Law et al. 2003). This is similar to the findings of Elliott et al. (2005) for great blue heron (Ardea herodias) and double-crested cormorant (Phalacrocorax auritus) eggs collected in the Strait of Georgia. Although BDE-209 was detected in those local eggs, it was not dominant. Law et al. (2003) suggested that this indicator congener for the deca-BDE formulation might be generally less bioavailable to biota in marine food chains. In a North Sea study, BDE-209 was the main congener measured in sediments, but it did not appear to be transferred to the food chain (Boon et al. 2002). If BDE-209 is sequestered to sediments, it might be more bioavailable to 
benthivores like surf scoters than to piscivores like herons and cormorants. That might explain why it was prevalent in liver samples during this study.

\section{Biological Changes Associated with Overwintering and Location}

The reduction in proportion of lymphocytes between late fall and early spring blood samples might indicate the presence of a low-level stressor in the marine environment of the Strait of Georgia. A high heterophil:lymphocyte ratio is often taken as a sign of stress in wild birds (Kilgas et al. 2006; Owen and Moore 2006; Wayland et al. 2002); however, there is some discussion about whether a reduction in lymphocytes is indicative of stress-induced immunosuppression (Hõrak et al. 1998; Smits and Williams 1999) or of a simple lack of parasitic infection (Ots and Hõrak 1998). Adrenal glands were examined for parasites in our study and no changes in the low-level presence of parasites were observed between fall and spring samples; hence, there was no evidence of an infectious agent that could explain the seasonal change in prevalence of lymphocytes.

We did observe a small but significant reduction in body condition of these adult male surf scoters over the course of the winter (Elliott et al. 2007), which was significantly associated with the changing proportion of lymphocytes. The relationship was more prevalent at the reference location, Baynes Sound, and more muted at Howe Sound, suggesting that the stress was not linked to the contaminant exposure response indicated by the elevated EROD activity at the latter location. Nonetheless, significant relationships were found between heterophil and lymphocyte proportions and hepatic concentrations of PCB 169.

Kilgas et al. (2006) found that the return rate of the great tit (Parus major) was higher for individuals that had a lower heterophil:lymphocyte ratio during the preceding breeding season. Hanauska-Brown et al. (2003) showed that the proportion of heterophils and lymphocytes were a reliable marker of body condition in Northern goshawks (Accipiter gentilis). It is of concern that mature male surf scoters exhibit poor body condition and a high heterophil: lymphocyte ratio just before they begin preparations for a northerly migration to breeding grounds, but there are few studies that assess the long-term impact of these conditions. There is some evidence that migratory passerines have naturally lower lymphocyte counts and reduced fat stores during their spring migration (Owen and Moore 2006), which would suggest these surf scoters were not abnormal. Additionally, at least one species of sea duck (the common eider, Somateria mollissima) paid a high price for mounting an immune response (expressed by high lymphocyte counts) during breeding; females injected with a nonpathogenic antigen while incubating eggs showed a reduced return rate (27\% compared to $72 \%$ ) if they responded against the antigen, implying that there was a severe cost to long-term survival (Hanssen et al. 2004). It is unclear what the impact of a low-level stress presence in early spring might have on the survival and reproductive capacity of surf scoters. Certainly, there is some indication that individuals migrating from the Strait of Georgia up the coast to spring herring spawn events in northern BC and Alaska rapidly increase in body mass (Esler et al. 2005; Lok et al. 2008). However, there are many other individuals that migrate up through inland $\mathrm{BC}$, where such a rich protein food source is not available. It would be worth investigating what proportion of the individuals exhibiting poor body condition and a high heterophil:lymphocyte ratio opt not to migrate and breed but rather remain on the wintering grounds.

The elevated EROD activity and associated reduced hematocrit in Howe Sound males was of interest. Hematocrit values in particular ranged as low as $18-23 \%$ for males and females, respectively, and these extreme anemic conditions would likely place a substantial stress on those individuals. Anemia might be indicative of bacterial or parasitic infections, a scarcity of some micronutrients, or starvation (Kilgas et al. 2006). There was no indication of heavy parasitic infection in the adrenal glands of these birds. Even birds taxed by the energetic demands of longdistance migration generally do not show hematocrits lower than 45\% (Owen and Moore 2006; Piersma et al. 1996).

Custer et al. (2000) found relatively elevated EROD activity in juvenile male scaups, as we found the most elevated response in juvenile females, and they saw a significant association between EROD activity and carcass PAH concentrations. We could find no association with EROD using mean values and the historically dominant forestry-sourced contaminants (e.g., PCDDs and PCDFs). Although we measured pyrene metabolites of PAHs and found no convincing evidence of a relationship with EROD, it is possible that other unmeasured PAHs commonly associated with pulp mills (particularly retene) were responsible for the Ah-receptor-mediated response. There are two pulp mills discharging secondary-treated effluent to Howe Sound. There is strong associative evidence to suggest that the EROD-inducing contaminant is also responsible directly or indirectly for the anemic condition of mature birds in the sound.

These individuals also showed relatively low levels of vitamin A and a significant positive association between EROD activity and hepatic retinyl palmitate concentrations (Harris et al. 2007). Thus, there is some cause for concern about the population of surf scoters wintering in Howe Sound, which might warrant further investigation of their health, contaminant, and productivity status. 
The porphyrin profiles in adult surf scoters were ambiguous. It was apparent that the metabolism of porphyrin and possibly its role in heme biosynthesis changed seasonally. It is probable that the metabolic changes observed between birds collected in late fall and early spring are migration-related changes in basic physiology. There are studies that show hemoglobin volumes change in species that undergo long-distance migrations (Piersma et al. 1996; Viscor et al. 1985).

It is less clear whether the differences in absolute concentrations of single porphyrins and total porphyrins among locations are biologically meaningful or consistent with natural variability for the species. Concentrations of the less common highly carboxylated forms (viz. hexa- and hepta-carboxylic acid porphyrins) were typically well above detection limits, unlike another sea duck, black guillemots (Kuzyk et al. 2003), but similar to herring gulls experiencing porphyria in the Great Lakes (Fox et al. 1988). Concentrations of highly carboxylated porphyrins were intermediate between herring gulls and guillemots from these two studies. Fox et al. (1988) associated increases in the highly carboxylated group with liver PCB concentrations greater than $10 \mu \mathrm{g} / \mathrm{g}$, values that are several-fold higher than the tissue burdens observed in our study.

Concentrations of protoporphyrin, an intermediate metabolite of heme biosynthesis, and coproporphyrin, one of its oxidative byproducts, were highest in birds from the urban Vancouver Harbour. Birds from this location were relatively contaminated with butyltins (Elliott et al. 2007), PCBs, and PBDEs; however, there were no significant associations between porphyrins and any of those contaminants. It is possible that the significant geographic differences reflect the cumulative tissue burden of contaminants and the higher burdens in birds from urban harbors. Conversely, the higher values observed for porphyrins in the harbor birds might be within the natural range for the species. The latter is supported by similar ranges (albeit lower mean values) for mature male birds collected from the reference site, Baynes Sound.

In summary, the biological markers chosen to evaluate condition and contaminant exposure in this study provided insight into the physiological state of overwintering surf scoters and highlighted some issues of concern that warrant further examination. Although organic contaminant concentrations were relatively low, elevated EROD activity indicated that the population in Howe Sound was responding to an Ah-receptor-mediated stressor, which was also affecting hematocrit values and possibly vitamin A status. In addition, the low proportion of lymphocytes in individuals across locations was associated with poor body condition in early spring, a time just prior to northerly migrations to breeding grounds. The implications of these biological indicators of compromised health for the productivity and survival of affected individuals and particularly of the population in Howe Sound warrant further evaluation, in light of the dramatic decline in Western populations of the species in recent decades.

Acknowledgments The authors thank to S. Lee, C. Copland, S. Boyd, T. Sullivan, D. LaCroix, C. Morrissey, C. Gill, and L. Barjaktarovic for assistance with field work, H. Gill for analysis of blood smears, and J. Smits for histopathological expertise. Assistance with biochemical and chemical assays was provided by G. SansCartier, F. Maisonneuve, G. Savard, B. Wakeford, H. Won, M. Mulvihill, M. Simon, J. Corriveau, D. Jeffrey, K. Williams, and A. Idrissi. For veterinary assistance in the field, thanks to M. McAdie and D. Bennett.

Open Access This article is distributed under the terms of the Creative Commons Attribution Noncommercial License which permits any noncommercial use, distribution, and reproduction in any medium, provided the original author(s) and source are credited.

\section{References}

Ariese F, Kok SJ, Verkaik M, Gooijer C, Velthorst NH, Hofstraat JW (1993) Synchronous fluorescence spectrometry of fish bile: a rapid screening method for the biomonitoring of PAH exposure. Aquat Toxicol 26:273-286

Boon JP, Lewis WE, Tjoen-A-Choy MR, Allchin CR, Law RJ, de Boer J et al (2002) Levels of polybrominated diphenyl ether (PBDE) flame retardants in animals representing different trophic levels of the North Sea food web. Environ Sci Technol 36:4025-4032

Custer TW, Custer CM, Hines RK, Sparks DW, Melancon MJ, Hoffman DJ, Bickham JW, Wickliffe JK (2000) Mixed-function oxygenases, oxidative stress, and chromosomal damage measured in lesser scaup wintering on the Indiana Harbor Canal. Arch Environ Contam Toxicol 38:522-529

Dods PL, Birmingham EM, Williams TD, Ikonomou MG, Bennie DT, Elliott JE (2005) Reproductive success and contaminants in tree swallows (Tachycineta bicolor) breeding at a wastewater treatment plant. Environ Toxicol Chem 24:3106-3112

Elliott JE, Martin PA (1998) Chlorinated hydrocarbon contaminants in grebes and seaducks wintering on the coast of British Columbia, Canada: 1988-1993. Environl Monit Assess 53:337362

Elliott JE, Harris ML, Wilson LK, Whitehead PE, Norstrom RJ (2001) Monitoring temporal and spatial trends in polychlorinated dibenzo-p-dioxins (PCDDs) and dibenzofurans (PCDFs) in eggs of great blue heron (Ardea herodias) on the coast of British Columbia, Canada, 1983-1998. Ambio 30:416-428

Elliott JE, Wilson LK, Wakeford B (2005) Polybrominated diphenyl ether trends in eggs of marine and freshwater birds from British Columbia, Canada, 1979-2002. Environ Sci Technol 39:55845591

Elliott JE, Harris ML, Wilson LK, Smith BD, Batchelor SP, Maguire J (2007) Butyltins, trace metals and morphological variables in surf scoter (Melanitta perspicillata) wintering on the south coast of British Columbia, Canada. Environ Pollut 149(1):114-124

Esler D, Lok E, Takekawa J (2005) Spring migration of surf scoters along the Pacific Coast: important habitats and energetic implications. Progress report to Sea Duck Joint Venture, October 2005. www.sdjv.com 
Fox GA, Kennedy SW, Norstrom RJ, Wigfield DC (1988) Porphyria in herring gulls: a biochemical response to chemical contamination of Great Lakes food chains. Environ Toxicol Chem 7:831-839

Fox GA, MacCluskie MC, Brook RW (2005) Are current contaminant concentrations in eggs and breeding female lesser scaup of concern? Condor 107:50-61

Hanauska-Brown LA, Dufty AM, Roloff GJ (2003) Blood chemistry, cytology, and body condition in adult northern goshawks (Accipiter gentilis). J Raptor Res 37:299-306

Hanssen SA, Hasselquist D, Folstad I, Erikstad KE (2004) Costs of immunity: immune responsiveness reduces survival in a vertebrate. Proc R Soc Lond 271(B):925-930

Harris ML, Wilson LK, Norstrom RJ, Elliott JE (2003) Egg concentrations of polychlorinated dibenzo- $p$-dioxins and dibenzofurans in double-crested (Phalacrocorax auritus) and pelagic ( $P$. pelagicus) cormorants from the Strait of Georgia, Canada, 1973-1998. Environ Sci Technol 37:822-831

Harris ML, Wilson LK, Trudeau SF, Elliott JE (2007) Vitamin A and contaminant concentrations in surf scoters (Melanitta perspicillata) wintering on the Pacific coast of British Columbia, Canada. Sci Total Environ 378(3):366-375

Henny CJ, Rudis DD, Roffe TJ, Robinson-Wilson E (1995) Contaminants and sea ducks in Alaska and the circumpolar region. Environ Health Perspect 103(Suppl 4):41-49

Herzke D, Gabrielsen GW, Evenset A, Burkow IC (2003) Polychlorinated camphenes (toxaphenes), polybrominated diphenylethers and other halogenated organic pollutants in glaucous gull (Larus hyperboreus) from Svalbard and Bjørnøya (Bear Island). Environ Pollut 121:293-300

Hites RA, Foran JA, Schwager SJ, Knuth BA, Hamilton MC, Carpenter DO (2004) Global assessment of polybrominated diphenyl ethers in farmed and wild salmon. Environ Sci Technol 38:4945-4949

Hõrak P, Ots I, Murumägi A (1998) Haematological health state indices of reproducing great tits: a response to brood size manipulation. Funct Ecol 12:750-756

Humason GL (1972) Animal tissue techniques. WH Freeman and Co, San Francisco

Kaiser GW, Derocher AE, Crawford S, Gill MJ, Manley IA (1995) A capture technique for marbled murrelets in coastal inlets. J Field Ornithol 66:321-333

Kennedy SW, James CA (1993) Improved method to extract and concentrate porphyrins from liver tissue for analysis by highperformance liquid chromatography. J Chromatogr Biomed Appl 619:127-132

Kennedy SW, Jones SP (1994) Simultaneous measurement of cytochrome P450IA catalytic activity and total protein concentration with a fluorescence plate reader. Anal Biochem 222:217223

Kilgas P, Tilgar V, Mänd R (2006) Hematological health state indices predict local survival in a small passerine bird, the great tit (Parus major). Physiol Biochem Zool 79:565-572

Kuzyk ZA, Burgess NM, Stow JP, Fox GA (2003) Biological effects of marine PCB contamination on black guillemot nestlings at Saglek, Labrador: liver biomarkers. Ecotoxicology 12:183-197

Law RJ, Allchin CR, Bennett ME, Morris S, Rogan E (2002) Polybrominated diphenyl ethers in two species of marine top predators from England and Wales. Chemosphere 46:673-681
Law RJ, Alaee M, Allchin CR, Boon JP, Lebeuf M, Lepom P, Stern GA (2003) Levels and trends of polybrominated diphenylethers and other brominated flame retardants in wildlife. Environ Int 29:757-770

Letcher RJ, Norstrom RJ, Lin S, Ramsey MA, Bandiera SM (1996) Immunoquantitation and microsomal monooxygenase activities of hepatic cytochrome P4501A and P4502B and chlorinated hydrocarbon contaminant levels in polar bear (Ursus maritimus). Toxicol Appl Pharmacol 137:127-140

Lim CK (1991) Porphyrins. In: Hanai T (ed) Liquid chromatography in biomedical analysis. Elsevier, Amsterdam, pp 209-232

Lin ELC, Cormier SM, Racine RN (1994) Synchronous fluorometric measurement of metabolites of polycyclic aromatic-hydrocarbons in the bile of brown bullhead. Environ Toxicol Chem 13:707-715

Lok EK, Kirk M, Esler D, Boyd WS (2008) Movements of premigratory surf and white-winged scoters in response to Pacific herring spawn. Waterbirds 31(3):385-393

Maxwell MH (1993) Avian blood leucocyte responses to stress. World's Poul Sci J 49:34-43

Norstrom RJ, Simon M, Muir DCG, Schweinsburg RE (1988) Organochlorine contaminants in arctic marine food chains: identification, geographical distribution, and temporal trends in polar bears. Environ Sci Technol 22:1063-1071

Ots I, Hõrak P (1998) Health impact of blood parasites in breeding great tits. Oecologia 116:441-448

Owen JC, Moore FR (2006) Seasonal differences in immunological condition of three species of thrushes. Condor 108:389-398

Peakall DB, Norstrom RJ, Rahimtula AD, Butler RD (1986) Characterization of mixed-function oxidase systems of the nestling herring gull and its implications for bioeffects monitoring. Environ Toxicol Chem 5:379-386

Piersma T, Everaarts JM, Jukema J (1996) Build-up of red blood cells in refueling bar-tailed godwits in relation to individual migratory quality. Condor 98:363-370

SDJVMB (Sea Duck Joint Venture Management Board) (2001) Sea Duck Joint Venture Strategic Plan 2001-2006. SDJV Continental Technical Team, US Fish and Wildlife Service, Anchorage AK/Canadian Wildlife Service, Sackville NB

Smits JE, Williams TD (1999) Validation of immunotoxicology techniques in passerine chicks exposed to oil sands tailings water. Ecotoxicol Environ Saf 44:105-112

Trudeau SF, Maisonneuve FJ (2001) A method to determine cytochrome P4501A activity in wildlife microsomes. Canadian Wildlife Service Tech Rep Ser No. 339. Environment Canada, Ottawa

Van den Berg M, Birnbaum L, Bosveld ATC, Brunström B, Cook P, Feeley M, Giesy JP, Hanberg A, Hasegawa R, Kennedy SW (1998) Toxic equivalency factors (TEFs) for PCBs, PCDDs, PCDFs for humans and wildlife. Environ Health Perspect 106:775-792

Viscor G, Marques MS, Palomeque J (1985) Cardiovascular and organ weight adaptations as related to flight activity in birds. Comp Biochem Physiol 82A:597-599

Wayland M, Gilchrist HG, Marchant T, Keating J, Smits JE (2002) Immune function, stress response, and body condition in Arcticbreeding common eiders in relation to cadmium, mercury, and selenium concentrations. Environ Res 90A:47-60

Wilkinson L (1990) SYSTAT: the system for statistics. SYSTAT, Evanston, IL 